日常場面におけるネガティブな感情経験がバーンアウト傾向に及ぼす影響：

ポジティブな感情経験を調整変数として

\author{
田 中 輝 海* 杉 山 佳 生**
}

\title{
The Influence of Daily Life Negative Affect Experience on \\ Burnout Tendency, Using Positive Affect Experience as a Moderating Variable ${ }^{\dagger}$
}

\author{
Terumi TANAKA* and Yoshio SUGIYAMA**
}

\begin{abstract}
In the present study, we focused on daily life affect experience, and aimed to confirm the promoting effect of negative affect and the suppressive effect of positive affect in aggravating burnout tendencies. Secondly, we aimed to examine the buffering effect of positive affect in suppressing the promoting effect of negative affect. Participants were university athletes (208 males and 68 females) who belonged to various athletic clubs.

First, multiple regression analysis was performed to confirm the promoting effect of negative affect and the suppressive effect of positive affect in aggravating burnout tendency. We set positive affect and negative affect as independent variables, and burnout tendency as the dependent variable. Positive affect and negative affect were evaluated with the Japanese version of the Positive and Negative Affect Schedule (PANAS), and burnout tendency was assessed with the Athletic Burnout Inventory.

Second, Hierarchical regression analysis was conducted to examine the buffering effect of positive affect in suppressing the promoting effect of negative affect. We set negative affect as the independent variable, positive affect as a moderating variable and burnout tendency as the dependent variable, and obtained the following findings:

1) In males as well as females, positive affect suppressed aggravation of burnout tendencies, while negative affect promoted aggravation of such tendencies.

In males as well as females, positive affect could not exert its buffering effect on suppressing aggravation burnout tendencies.
\end{abstract}

Key words : University Student-athletes, Positive Psychology, Burnout Syndrome, Hierarchical Regression Analysis

\footnotetext{
${ }^{\dagger}$ 原稿受付 2015 年 9 月 28 日 原稿受諾 2015年12月 1 日

*九州大学大学院人間環境学府 $=816-8580$ 福岡県春日市春日公園 $6-1$

***州大学大学院人間環境学研究院 $=816-8580$ 福岡県春日市春日公園6-1

* Graduate School of Human-Environment Studies, Kyushu University, 6-1, Kasuga-koen, Kasuga, Fukuoka, Japan (816-8580)

** Faculty of Human-Environment Studies, Kyushu University, 6-1, Kasuga-koen, Kasuga, Fukuoka, Japan (816-8580)
} 
1. 緒 言

スポーツ障害や摂食障害, オーバートレーニ ングといった競技生活の継続を脅かす問題は, これまでに様々な側面から検討されている。 中 でも, 特に深刻な問題として自殺やうつ病と いった精神病理学的な問題に波及することが危 惧されるバーンアウトがある ${ }^{1)}$. バーンアウト とは燃え尽き症候群とも呼ばれ, 主に対人援助 職領域で扱われる概念であり，自分自身に非現 実的な目標を設定し, その達成に向けて努力し 続けた結果として心身が枯渇することを指す ${ }^{2)}$. また，その症状は個人により異なるが, 主に不 安や怒り, 悲哀感などの精神症状と頭痛や腰痛, 睡眠障害などの身体症状の 2 つに分けられ ${ }^{3) 4}$ ， 吉田 ${ }^{5)}$ は, 軽度のバーンアウトであれば, 精神 症状だけが認められるが, 重度の場合には, 精 神症状に加え身体症状を呈することを示唆して いる.

このバーンアウトの概念をスポーツ領域に用 いて, スポーツ選手特有の発症要因の解明や予 防法の確立を目的とした研究 ${ }^{6)}{ }^{7)}$ は多く, その
関心は高い. しかしながら，スポーツ領域の バーンアウトを明確に捉えた定義は存在してお らず，研究手法などにより異なる．国内のバー ンアウト研究では, 岸 ${ }^{8)}$ が提示した「スポーツ 活動や競技に対する意欲を失い，文字通り燃え 尽きたように消耗・疲弊した状態」とする定義 がコンセンサスを得ている，また，スポーツ領 域で提示されたバーンアウトの理論モデルも, バーンアウトの発症過程を理論化したモデル ${ }^{1) 9}$ や，競技へのコミットメントスタイルに焦点を 当てたモデル ${ }^{10)}$ など, 多方面から提示されてい る。本研究は，バーンアウト傾向の悪化に及ほ すネガティブ感情の促進効果およびポジティブ 感情の抑制効果の解明を目的とするため, バー ンアウトの発症までの感情や自己認知, 対人関 係の変化過程を詳細に捉えている心理臨床モデ ル ${ }^{1)}$ に基づき研究を進める（図 1)。このモデ ルに従えば，スポーツ選手は，成功経験から高 い目標を掲げ競技に熱中する（「熱中」状態）. その後, 怪我やスランプなどにより競技成績が 停滞してしまう (「停滞」状態)。しかし，そこ で揭げた目標を下げることなく，競技活動への

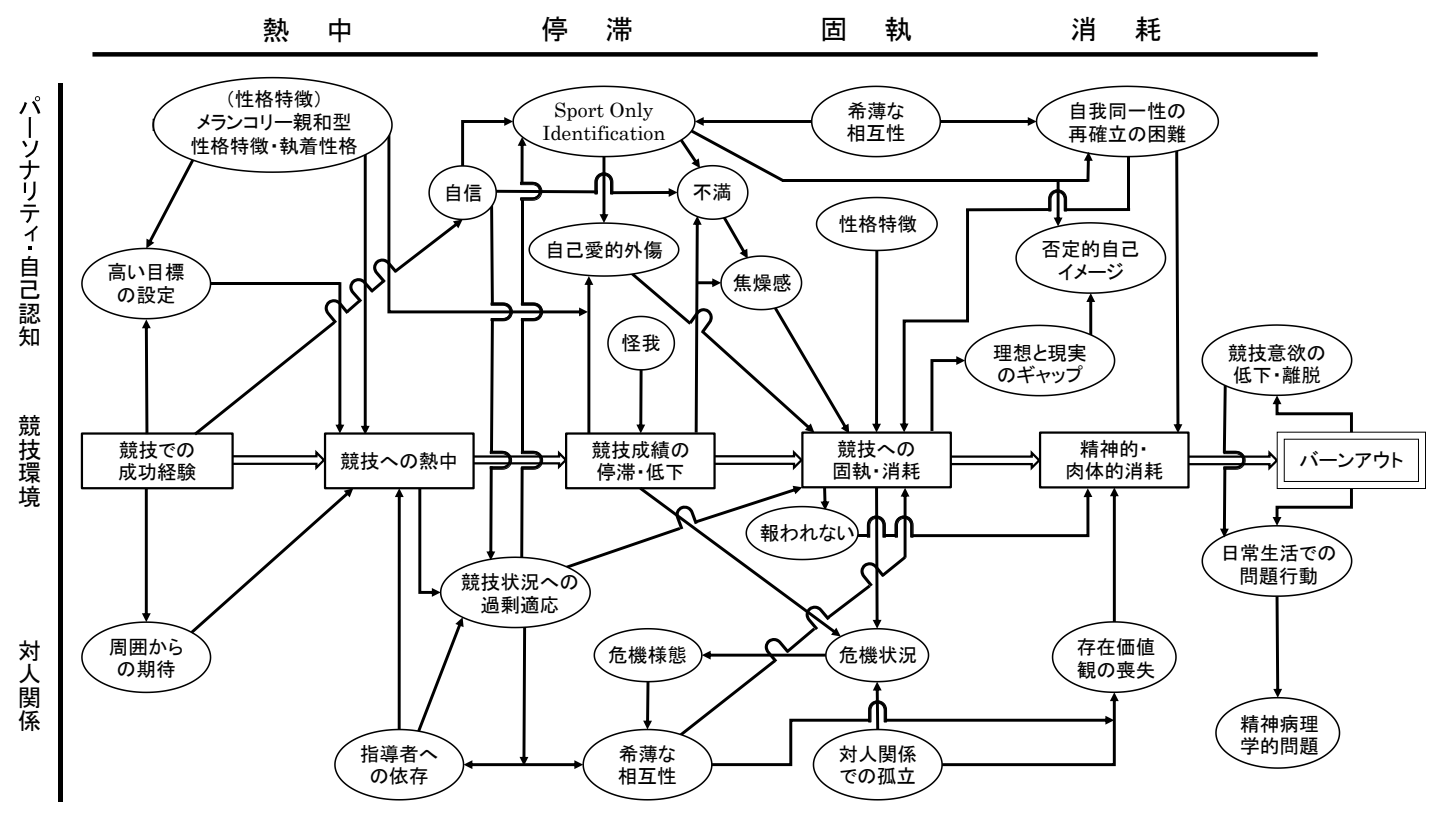

図 1 運動選手におけるバーンアウトの発症機序（中込・岸, 1991をもとに作成） 
固執をさらに強めていく(「固執」状態).そし て，報われることなく精神的にも肉体的にも疲 弊してしまう(「消耗」状態)。このようなプロ セスを経て, バーンアウトの発症に至る.

心理臨床モデルにも示されているように, バーンアウトは長期的なプロセスを経て発症す る精神的な病理現象であり, その発症要因を特 定することは難しい. その中で, 多くの研究で 報告されている要因として, 日常・競技場面に おけるストレス, 執着気質やメランコリー親和 型性格といったバーンアウトを発症しやすいと される性格特徴が挙げられる ${ }^{4) 611) . さ さ ら に, ~}$ いくつかの理論モデル ${ }^{1 / 9)} に$ 組み込まれている ネガティブ感情もバーンアウト傾向の悪化を促 進することが実証されている ${ }^{1213)}$. 鈴木 ${ }^{14)}$ や山 崎 ${ }^{15)}$ のレビューによれば, ネガティブ感情には, 注意や思考の範囲を狭め, 対峙する問題に対し て局所的な処理を促進させる機能がある.この 機能は, 競技への盲目的な取り組みを促す危険 性があり, 心理臨床モデルにおける「停滞」状 態から「固執」状態へ移行させてしまうなど, バーンアウトの発症に寄与することが考えられ る.

これに対して, 楽しさや喜び, 興味などの総 称であるポジティブ感情には, バーンアウトの 発症を抑える機能があると考えられている ${ }^{16)}$. この感情には, 柔軟かつ創造的な認知や思考を もたらし, 困難に直面した際には複数の解決策 の考案に貢献するとされ ${ }^{17) 18) 19)}$, 例えば, 競技 成績の伸び悩みといったストレス事象に対して も,「固執」状態, すなわち競技への過剩適応 とは異なる対処法の考案に役立つと思われる. さらに, 鈴木 ${ }^{14)}$ や Fredrickson et $\mathrm{al}^{20}{ }^{20}$ によれば, ポジティブ感情にはネガティブ感情による心理 的な緊張や心拍数の上昇などの生理的な反応を 軽減させる機能がある。これに関して, 田中 ・ 水落 ${ }^{21)}$ は, 普段からポジティブな感情経験が多 い選手ほど, バーンアウト傾向を悪化させるネ ガテイブ感情の影響は軽減しやすいことを示唆 している.

以上のことから，日常的に経験するポジティ
ブ感情は, バーンアウトの発症を直接的に抑え るだけではなく，その発症を促すネガティブ感 情の影響を緩衝することが推察される。しか し, 田中・水落 ${ }^{21)}$ は, ネガティブ感情およびポ ジティブ感情の経験頻度別群間におけるバーン アウト傾向得点の平均值の差を一要因分散分析 により検討しているため，ネガティブ感情の促 進効果を抑えるポジティブ感情の緩衝効果を検 討していない。 また, 感情は, 持続時間が短く, 一時的な経験を指す感情状態と, 個人の傾向で あり, 特定の感情の経験しやすさを指す感情特 性に区別される2223)。このことから，ネガティ ブな感情特性が高い選手，つまりネガティブ感 情を経験しやすい選手ほど, 競技場面において もネガテイブ感情を経験しやすく，バーンアウ 卜傾向は悪化していることが考えられる。 しか し, 先行研究 ${ }^{1213)}$ では, 競技場面におけるネガ ティブ感情に焦点が当てられており，日常場面 におけるネガティブな感情経験がバーンアウト 傾向に及ぼす影響を実証した研究は確認されて いない.

そこで本研究では, 日常場面における感情経 験に着目し，まずスポーツ選手を対象にバーン アウト傾向の悪化に及ぼすネガティブ感情の促 進効果拉よびポジティブ感情の抑制効果を確認 する. 次に，ネガティブ感情による促進効果を 抑える，ポジティブ感情の緩衝効果を検討する ことを目的とした．バーンアウト傾向の悪化に 及ぼすそれぞれの感情の働きが解明されること で, バーンアウトの予防法の開発の基礎となる だけではなく，両感情が備え持つ新たな機能を 見出す手がかりになると思われる.

なお，スポーツ領域におけるバーンアウトの

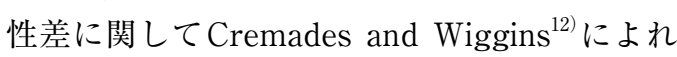
ば，男性選手と比べ女性選手は，バーンアウト を発症しやすいようである。また，石井 ${ }^{24)}$ は， 女性選手の心理的特性として, 失敗を恐れて過 剩に心配してしまうなど, 情緒的に不安定にな りやすいことを報告している，さらに，日常場 面で喚起する感情にも性差が確認されている ことから ${ }^{25)}$, 性の違いにより, バーンアウト傾 
向に及ぼす感情の影響は異なることが推察され る.したがって, 本研究では性ごとに検討する こととした.

\section{2. 研 究 方 法}

\section{1 調査対象と調査時期}

大学生スポーツ選手294名を対象にフェイス

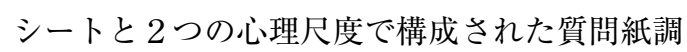
査を実施した。 そして, 回答に不備があった者 18名を除いた，競技活動を継続していることが 認められる男性選手208名, 女性選手68名, 計 276 名（平均年齢 $19.7 \pm 1.0$ 歳）の回答を分析対 象とした. 調査は大学の授業の前後を利用した 集合法により実施した.いずれも回答後すぐに 回収した. 調査は, 事前に調査目的や個人情報 の管理, 回答・無回答に関わらず個人の不利益 は生じないことを書面と口頭で行い, 調査協力 に対して同意が得られた者を対象に行った。調 査時期は2015年 7 月であった.

\section{2 質問項目}

フェイスシート：氏名, 年齢, 性別, 運動部 あるいはスポーツ系サークルへの所属と競技活 動の有無について回答を求めた.

日本語版Positive and Negative Affect Schedule (PANAS) : Watson et $\mathrm{al}^{26)}$ が作成したPANAS をもとに, 佐藤・安田 ${ }^{27)}$ が, 日本語版として作 成した尺度であり，「ネガティブ感情」(NA) 因子と「ポジティブ感情」(PA) 因子の 2 因子 を評定する。この尺度は,「苦悩した」,「心配 した」などの 8 項目から評価されるNA因子と, 「活気のある」，「わくわくした」などの 8 項目 から評価されるPA因子の 2 因子 16 項目の質問 からなり, 回答は, 「全くなかった (1 点) 」,「めっ たになかった（2 点)」,「ときどきあった（3 点)」,「しばしばあった (4 点)」,「ほとんどい つもだった（5点)」,「いつもそうだった（6 点)」の 6 件法で評定させた. 得点が高いほど ネガティブ感情あるいはポジティブ感情の経験 量が多いと解釈される。 この尺度の信頼性につ いて, 佐藤 ·安田 ${ }^{27)}$ は, NA因子, PA因子の $a$ 係数はいずれも.80以上と高い内的整合性を 確認している.ささらに, 両因子が目的通りネガ ティブ感情とポジティブ感情を評価しているか どうかを, 気分導入下での評定值から検討し, それらの内容的妥当性を確認している. 本研究 では, 両感情の経験しやすさを測定するために, 最近 1 ケ月間における各感情の経験頻度を評定 するよう調査対象者に教示を与えた。

運動選手のバーンアウト尺度（Athletic Burnout Inventory : ABI) : Maslach and Jackson $^{28)}$ が作成した Maslach Burnout Inventory（MBI）を岸ら ${ }^{29)}$ が邦訳し，競技場面を想 定して作成したスポーツ選手のバーンアウト傾 向を測定するための尺度である。この尺度は, 「私は自分の競技生活にうんざりしている」,「私 は競技に行き詰っていると感じている」などの 8 項目から評価される「競技に対する情緒的消 耗感」因子,「私はチームに自分なりに貢献し ている(逆転項目)」,「私の役割やチームへの 貢献はメンバーから十分に認められている（逆 転項目)」などの 5 項目から評価される「個人 的成就感の低下」因子，「周りの人達は私を快 く思っていない」,「チームメイトとのコミュニ ケーションが少なくなった」などの 3 項目から 評価される「チームメイトとのコミュニケー ションの欠如」因子,「私の競技生活は, これ まで非常に価值のあるものだった(逆転項目)」, 「私はチームメイトと練習した後は有意義な気 持ちになる (逆転項目)」などの 3 項目から評 価される「競技への自己投入の混乱」因子の 4 因子19項目の質問からなり，回答は「全く当て はまらない（1 点)」,「あまり当てはまらない ( 2 点) 」,「どちらともいえない（3 点)」,「少 し当てはまる（4 点)」,「かなり当てはまる（ 5 点)」の 5 件法で評定させた。 また, 各因子得 点の合計得点をバーンアウト傾向得点とした. バーンアウト傾向得点が高いほど, 深刻なバー ンアウト状態とされる。この尺度の信頼性につ いて岸ら ${ }^{29)}$ は, ABIがMBIにほぼ対応する因 子構造であり, 全体の $\alpha$ 係数は.86と高い内的 整合性を確認している，さらに，競技生活状況 
表 1 分析に用いた変数の基本統計量

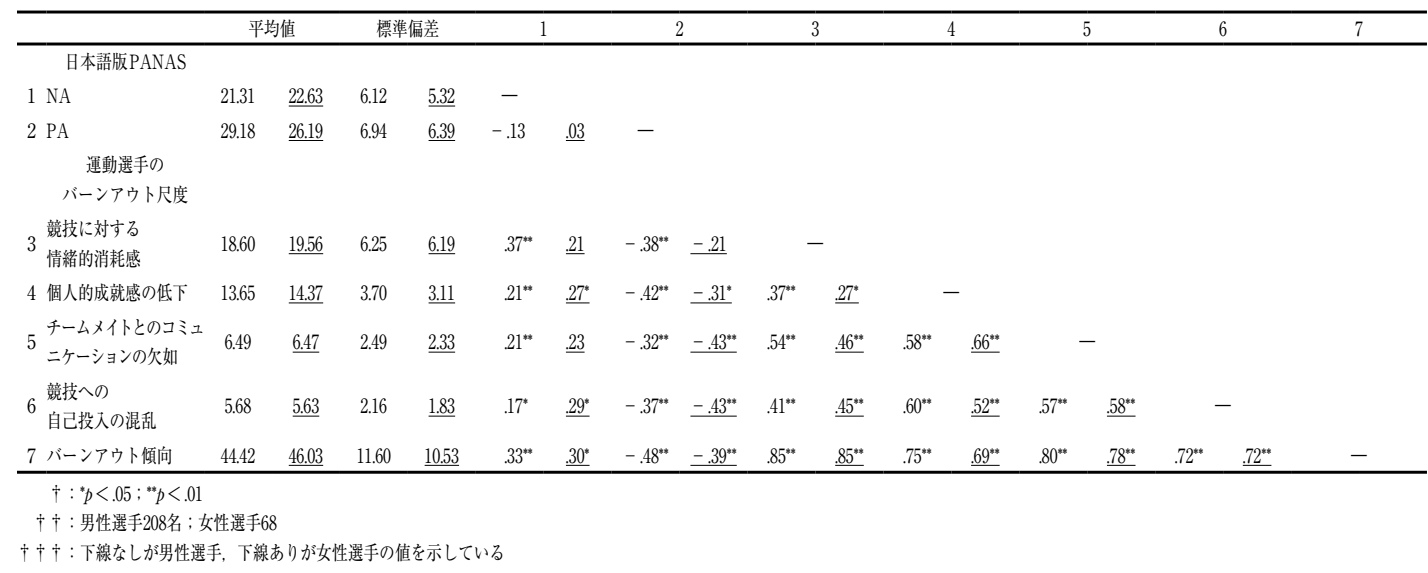

の自己評価との比較, 体協競技意欲検査, 日本 語版Profile of Mood States (POMS), スポー ッマン的同一性尺度との関連を検討し, 基準関 連妥当性を確認している.なお，バーンアウト を同定するにはこの尺度のみでは困難であり， この尺度はバーンアウトの発症を判定するとい うよりも，スポーツ選手のバーンアウト傾向の 把握のために利用される.

\section{3 データ処理}

まず，日本語版PANASにおけるNA因子得 点およびPA因子得点, ABIにおける各因子得 点とその総和であるバーンアウト傾向得点の平 均值と標準偏差を算出し, さらにそれらの関係 性をPearsonの相関係数により求めた.

次に, バーンアウト傾向の悪化に及ぼすネガ ティブ感情の促進効果およびポジティブ感情の 抑制効果を検証するため, NA 因子得点と PA 因子得点を独立変数とし, バーンアウト傾向得 点を従属変数として予測する重回帰分析を強制 投入法によって行った.

最後に, ネガティブ感情の促進効果を抑える ことで, 間接的にバーンアウト傾向の悪化を抑 えるポジティブ感情の緩衝効果を検証するた め, NA因子得点を独立变数, PA因子得点を 調整変数, バーンアウト得点を従属変数とする 階層的重回帰分析を行った. Step 1 としてNA
因子得点と PA 因子得点を, Step 2 として交互 作用項（NA因子得点 $\times$ PA因子得点）を投入 した。なお,多重共線性の問題を回避するため, 前田 ${ }^{30)}$ の手順に従い, 各PA因子得点から PA 因子得点の平均值を減じる中心化による值を分 析に使用した。

なお,すべての統計分析には, 統計解析ソ フトSPSS Statistics 22を用いた. 有意水準は, $5 \%$ 未満に設定した.

\section{3. 結}

果

\section{1 各変数の基本統計量}

分析に用いた各変数の平均值と標準偏差を算 出し, さらにそれらの関係性をPearsonの相関 係数により求めた（表 1 ). 日本語版PANAS 間の関係を見ると, 男性選手と女性選手と もにNA因子得点と PA因子得点に相関はな かった（それぞれ，r=-.13, $p>.05 ; r=.03$, $p>.05)$.また, NA因子得点と $\mathrm{ABI}$ の各得点 の関係をみると, 男性選手におけるNA因子得 点は, 競技に対する情緒的消耗感因子得点 $(r$ $=.37, p<.01)$, 個人的成就感の低下因子得点 $(r$ $=.21, p<.01)$, チームメイトとのコミュニケー ションの欠如因子得点 $(r=.21, p<.01)$, 競技 への自己投入の混乱因子得点 $(r=.17, p<.05)$, バーンアウト傾向得点 $(r=.33, p<.01)$ と正 の相関があった，一方，女性選手における NA 
表 2 強制投入法による重回帰分析の結果

\begin{tabular}{|c|c|c|c|c|}
\hline \multirow{3}{*}{ 独立変数 } & \multicolumn{4}{|c|}{ 従属変数（バーンアウト傾向） } \\
\hline & \multicolumn{2}{|c|}{ 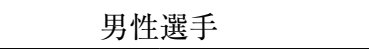 } & \multicolumn{2}{|c|}{ 女性選手 } \\
\hline & $\beta$ & $t$ & $\beta$ & $t$ \\
\hline NA & .28 & $4.68^{* * *}$ & .31 & $2.92^{* * *}$ \\
\hline $\mathrm{PA}$ & -.44 & $7.46^{* * *}$ & -.40 & $3.67^{* * *}$ \\
\hline$R^{2}$ & .30 & $F=1412 * * *$ & .25 & $F=11068^{* * *}$ \\
\hline 調整済み $R^{2}$ & .29 & $F=44.13$ & .22 & $F=10.68$ \\
\hline
\end{tabular}

因子得点は, 個人的成就感の低下因子得点 $(r$ $=.27, p<.05)$, 自己投入の混乱因子得点 $(r=.29$, $p<.05)$, バーンアウト傾向得点 $(r=.30, p<.05)$ と正の相関があった。 また, PA因子得点と $\mathrm{ABI}$ の各得点との関係をみると, 男性選手にお ける PA因子得点は, 競技に対する情緒的消耗 感因子得点 $(r=-.38, p<.01)$, 個人的成就感 の低下因子得点 $(r=-.42, p<.01)$, チームメ イトとのコミュニケーションの欠如因子得点 $(r$ $=-.32, p<.01)$, 競技への自己投入の混乱因 子得点 $(r=-.37, p<.01)$, バーンアウト傾向 得点 $(r=-.48, p<.01)$ と負の相関があった. 一方, 女性選手における $\mathrm{PA}$ 因子得点は, 個人 的成就感の低下因子得点 $(r=-.31, p<.05)$, チームメイトとのコミュニケーションの欠如因 子得点 $(r=-.43, p<.01)$, 自己投入の混乱因 子得点 $(r=-.43, p<.01)$, バーンアウト傾向 得点 $(r=-.39, p<.01)$ と負の相関があった.

\section{2 バーンアウト傾向に及ぼすネガティブ 感情およびポジティブ感情の影響の検証}

バーンアウト傾向の悪化に及ぼすネガティブ 感情の促進効果およびポジティブ感情の抑制効 果を検証した結果, 男性選手においてバーンア ウト傾向得点に対してNA因子得点と PA因子 得点のそれぞれで有意な主効果が認められた $(\beta=.28, p<.001 ; \beta=-.44, p<.001)$. 同様に, 女性選手においてもそれぞれ有意な主効果が認 められた $(\beta=.31, p<.001 ; \beta=-.40, p<.001)$ (表2).

\section{3 ネガティブ感情による促進効果を抑え るポジティブ感情の緩衝効果の検証}

ネガティブ感情の促進効果を抑えることで, 間接的にバーンアウト傾向の悪化を抑えるポジ ティブ感情の緩衝効果を検証した結果, 男性選 手における階層的重回帰分析の結果, 有意な交 互作用は認められなかった $(\beta=.02, p>.05)$ (表 3). 同様に, 女性選手に打いても有意な交互 作用は認められなかった $(\beta=-.25, p>.05)$ (表 $4)$.

\section{4. 考察}

\section{1 バーンアウト傾向の悪化に及ぼすネガ}

\section{ティブ感情およびポジティブ感情の影響}

バーンアウト傾向の悪化に及ぼす両感情の影 響を検討した結果, 性の違いに関わらずバーン アウト傾向の悪化に対してネガティブ感情は弱 い正の影響力を示し，ポジティブ感情は中程度 の負の影響力を示した.

まず，バーンアウト傾向の悪化を促進させる ネガティブ感情の影響から考察を試みる. 速水 ${ }^{31)}$ は, 失敗を繰り返すことで, 無気力感の喚起 に伴い動機づけが低下することを示唆してお り,さらにCarver ${ }^{32)}$ は, 目標達成に遠く及ば ない結果であった際に知覚する悲しみや失望な どのネガティブ感情も動機づけを低下させるこ とを示している. 加えて, バーンアウトは, 過 度な期待や高すぎる理想を掲げ努力を続ける が，報われることなく心身が枯渇することで発 症する症候群 ${ }^{4)}$ とされ，選手が抱く理想と現実 
表 3 男性選手におけるバーンアウト傾向を従属変数とした階層的重回帰分析の結果

\begin{tabular}{lccccc}
\hline \multirow{2}{*}{ Step と投入した変数 } & \multicolumn{2}{c}{ Step 1} & \multicolumn{3}{c}{ Step 2 } \\
\hline Step 1 & NA & .28 & $4.68^{* * *}$ & $\beta$ & $t$ \\
& PA & -.44 & $7.46^{* * *}$ & & \\
Step 2 & $\mathrm{NA} \times \mathrm{PA}$ & & & .02 & .09 n.s. \\
& $R^{2}$ & .30 & $F=44.13^{* * *}$ & .30 & $F=29.28^{* * *}$ \\
& $\Delta R^{2}$ & & & .00 & $F=\quad .01$ n.s. \\
\hline$\dagger:{ }^{* * *} p<.001$ & & &
\end{tabular}

表 4 女性選手におけるバーンアウト傾向を従属変数とした階層的重回帰分析の結果

\begin{tabular}{lcrrrr}
\hline \multirow{2}{*}{ Step と投入した変数 } & \multicolumn{2}{c}{ Step 1 } & \multicolumn{3}{c}{ Step 2 } \\
\hline Step 1 & NA & -.31 & $2.92^{* * *}$ & & \multicolumn{1}{c}{$t$} \\
& PA & .40 & $3.67^{* * *}$ & & \\
Step 2 & NA $\times$ PA & & & -.25 & .59 n.s. \\
& $R^{2}$ & .25 & $F=10.68^{* * *}$ & .25 & $F=7.17^{* * *}$ \\
& $\Delta R^{2}$ & & & .00 & $F=.35$ n.s. \\
\hline$\dagger:{ }^{* * *} p<.001$ & & & \\
$\dagger \dagger: \mathrm{N}=68$ & & &
\end{tabular}

のギャップにより生じる不満や焦燥感などのネ ガティブ感情が, バーンアウトの発症に促進的 に影響することが想定されている ${ }^{1) 91}$ 。このネ ガティブ感情には, 注意範囲を拡張させ, 柔軟 かつ創造的な認知や思考をもたらすポジティブ 感情とは対照的な機能があり, 注意範囲を狭め ることで, 局所的な処理を促進させる ${ }^{14) 15(18) 33) . ~}$ つまり，普段からネガティブ感情を経験しやす い選手ほど，心理臨床モデルにおける「停滞」 状態において，様々なネガティブ感情を喚起し やすいことが考えられる.さらに，この喚起さ れた感情は, 競技ストレスへの対処として「固 執」状態を強化させるが, この対処行動では, 本質的な問題を解決することはできず，動機づ けの低下や「消耗」状態への移行, ひいてはバー ンアウトの発症に至ることが推察される.

ネガティブ感情は, 様々なバーンアウトの理

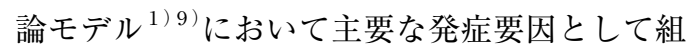
み込まれているように，その発症に影響を及ぼ すことは広く知られている。 バーンアウトの発
症に与えるネガティブ感情の影響を実証的に検 討した研究は少ないがその中でCremades and Wiggins ${ }^{12)}$ やLemyre et al. ${ }^{13)}$ は, バーンアウト 傾向を悪化させるネガティブ感情の促進効果を 実証している．ただし，これらの研究は競技特 性不安や競技場面に限定したネガティブ感情に 焦点を当てており，スポーツ選手の日常的に経 験するネガティブ感情がバーンアウト傾向に及 ぼす影響は明らかにされていない。本研究の結 果により，日常場面で経験するネガティブ感情 がスポーツ領域におけるバーンアウトの発症を 促進することが実証された.

一方で，本研究においても日常場面における ポジティブな感情経験がバーンアウト傾向の悪 化を抑制するという先行研究16) と同様の結果が 得られた.このポジティブ感情には, 良好な対 人関係の促進 ${ }^{17)}$ や, 競技活動そのものが目的と なっている状態である内発的動機づけを向上さ せる機能があると示唆されている ${ }^{34)}$. Raedeke and $\mathrm{Smith}^{35)}$ は, この内発的動機づけとバーン 
アウト傾向の悪化は抑制的な関係にあることを 示している.つまり, 普段からポジティブ感情 経験をしやすい選手ほど, 競技場面においても 望ましい対人関係を築けるため, 競技環境への 適応感は高まることが考えられる.ささらにこ のような選手は, 競技活動を楽しみ, 新たなス キルの獲得や更なる上達に興味を持ちやすいた め, 内発的動機づけが高まり, バーンアウト傾 向の悪化は抑えられることが推察される. しか しながら, 本研究からは, 日常場面におけるポ ジティブな感情経験が競技適応感および内発的 動機づけを高めることで, バーンアウトの発症 を抑えるといった一連の関係性までは検証でき ず, 今後の研究課題となる.

\section{2 ネガティブ感情の促進効果を緩和する ポジティブ感情の緩衝効果}

バーンアウト傾向の悪化を促進させるネガ ティブ感情の影響を緩和するポジティブ感情の 緩衝効果を検討した結果, 男女ともにポジティ ブ感情はネガティブ感情の促進効果には影響し ないことが示された。

鈴木 ${ }^{14)}$ は「ポジティブ感情の機能のひとつは, ネガティブ感情によって高められた，あるいは 高められると予想される心理的緊張や生理的覚 醒を素早く元に戻す undoing 効果や軽減効果に あると考えられる」と述べている. しかしなが ら, 本研究の結果より, 性別を問わずネガティ ブ感情の促進効果を軽減するポジテイブ感情の 緩衝効果は確認されなかった。つまり, 本研究 の仮説とは異なる結果が得られたことになる.

仮説が採択されなかった理由の一つに, ネガ ティブ感情とポジティブ感情の関係性が考えら れる. 本研究では, 普段からポジティブ感情を 経験しやすい選手ほど，ネガティブ感情による 促進効果は軽減することを想定していたが, 本 研究の結果で示された通り, ネガティブ感情と ポジティブ感情の間に相関関係は認められず, 両感情経験がバーンアウト傾向の悪化に及ぼす 影響は，それぞれ独立していることが考えられ る. 加えて, Fredrickson et al. $^{20)}$ が示している undoing 効果の持続性の問題も挙げられる. そ こでは, 一過性の刺激により生じるネガティブ 感情の影響を打ち消すポジティブ感情の機能に 焦点が当てられている. しかし，バーンアウト は競技ストレスやネガティブ感情に繰り返し曝 されることで発症する症候群である ${ }^{1) 91}$.つま り，ネガティブ感情の影響を抑えるポジティブ 感情の緩衝効果は，ネガテイブ感情による一時 的な影響に対して発揮されるが，長期的・持続 的に影響することはないと考えられる。これら のことから，日常場面におけるネガティブな感 情経験による影響を軽減させる，ポジティブな 感情経験の緩衝効果は確認されなかったことが 推察される.

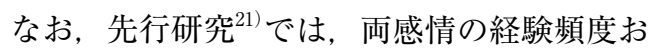
よびバーンアウト傾向の相互関係を一要因分散 分析により検討しているため，ネガティブ感情 の促進効果を抑えるポジティブ感情の緩衝効果 は分析されていない，本研究では，階層的重回 帰分析を用いているため, より精細にポジティ ブ感情の緩衝効果を検証したことになる。

一方で，日常場面におけるポジティブ感情の 経験頻度に応じて, バーンアウトの発症を促す ネガティブ感情の影響力が変化するのであれ ば，それには別の要因が介在している可能性が 高い.とりわけ，「ストレス事態に対して何ら かの対処を行うこと ${ }^{36)}$ とされるコーピングを 媒介していることが考えられる. Raedeke and Smith ${ }^{37)}$ は, 一般的なコーピングを用いること で，競技ストレスを適切に対処でき，その結果 としてバーンアウトの発症を抑制できることを 示唆している. ポジティブ感情には, いくつか のコーピングを促進させる機能があり ${ }^{17) 19)}$ ， ポ ジティブ感情との関連が報告されているのは, 積極的に問題の解決を試みる「問題解決」と, 問題に対して肯定的な解釈を試みる「認知的 再解釈」の 2 つの位概念からなる問題焦点 型コーピングであるとされる ${ }^{15)}$.さらに, この コーピングは, バーンアウトの抑制 ${ }^{38)}$ のなら ず，抑うつ反応 ${ }^{39}$ や競技ストレス反応 ${ }^{40)}$ を軽減 することが示唆されている。 そこで, これらの 
関係性を検討した田中・杉山 ${ }^{16)}$ により，日常的 にポジティブ感情を多く経験することで, 適切 なコーピング方略が促進され, その結果として バーンアウト傾向の悪化は抑制されるとする因 果モデルが提示されている，つまり，普段から ポジティブ感情を経験しやすい選手は, 心理臨 床モデルにおける「停滞」状態といったストレ スに曝されていても, その対処として適切な目 標や練習メニューの再設定, 十分な休息などに より，「固執」状態を強めることを抑制するこ とができると思われる，したがって，多様な競 技ストレスに曝される状況においても, 田中 . 杉山到) が示しているように, ポジティブ感情に より問題焦点型コーピングが促進されること で，バーンアウト傾向の悪化を防げることが示 唆される。

また, 岡ら ${ }^{41)}$ は, 大学生スポーツ選手は, 競 技成績の伸び悩みや他者からの過度の期待と いった競技に関するストレスに限らず，競技と 学業の両立や対人関係における問題など, 日常 場面においてもストレスに曝される危険性があ ることを示唆している. さらに, 阿久津ら ${ }^{42)}$ は, ストレスに曝されることによりネガティブ感情 が増大することを報告している.このことから， 日常的にネガティブな感情経験が多い選手は, 様々なストレスを抱えていることが想定され， 適切なコーピングによるストレス軽減効果は大 きいと思われる。

以上のことから, 先行研究 ${ }^{21)}$ では, 普段から ポジティブな感情経験が多い選手は, ネガティ ブ感情のバーンアウトに対する促進効果を抑え る機能が発揮されやすいとされているが, それ は, 日常場面におけるポジティブな感情経験に よるバーンアウト傾向の悪化を直に抑える直接 効果と, ポジティブな感情経験が競技ストレス へ対処する問題焦点型コーピングを促進させる ことで, バーンアウト傾向の悪化を抑える媒介 効果の 2 つの相乗効果によるものと推察され る.

\section{5. ま め}

本研究は, 日常場面における感情経験に着目 し，バーンアウト傾向の悪化に及ぼすネガティ ブ感情の促進効果およびポジティブ感情の抑制 効果を確認すること, さらに，ネガティブ感情 の促進効果を抑えるポジティブ感情の緩衝効果 を検討することを目的とした，分析対象は，又 ポーツ活動を継続的に行っている大学生（男性 208名, 女性68名）であった。

本研究の結果より, 以下の知見が得られた.

1 ）性の違いに関わらず, バーンアウト傾向の 悪化に対してネガティブ感情は促進的に作 用し，ポジティブ感情は抑制的に作用する ことが確認された。

2 ）性の違いに関わらず，ネガティブ感情によ る促進効果を抑えるポジティブ感情の緩衝 効果は確認されなかった.

今後の研究課題として，スポーツ選手を対象 に日常場面におけるポジティブ感情の経験量を 増加させる介入方法 ${ }^{43) 44)}$ を用いて, 田中・杉山 ${ }^{16)}$ の因果モデルに基づく，ポジティブ感情が問題 焦点型コーピングを促進することでバーンアウ トの発症を抑制するといった因果関係を解明す ることが挙げられる.

\section{参 考 文 献}

1) 中込四郎, 岸 順治; 運動選手のバーンアウ 卜発症機序に関する事例研究, 体育学研究, Vol.35, pp.313-323, 1991.

2) フロイデンバーガー：川勝 久訳 ; スランプ をつくらない生きかた：バーン・アウトシン ドローム, 三笠書房, 1981.

3) 稲岡文昭; 米国におけるBurnoutに関する概 要. 研究の動向, 今後の課題, 看護研究, Vol.21, pp.140-146, 1988.

4 ）岸順治, 中込四郎; 運動選手のバーンアウト 症候群に関する概念規定への試み, 体育学研究, Vol.34, pp.235-243, 1989.

5 ）吉田 毅 ; スポーツ的社会化論からみたバー ンアウト競技者の変容過程, スポーツ社会学研 究, Vol.2, pp.67-79, 1994. 
6) 木村 彩, 他; 大学生スポーツ選手における バーンアウトとストレッサーの関係, 健康科学, Vol.35, pp.25-31, 2013.

7 ) 土屋裕睦；ソーシャルサポートを活用した スポーツカウンセリング. 風間書房, pp.1-37, 2012.

8 ）岸 順治; 運動選手のバーンアウトの理解と対 処. Japanese Journal of Sports Sciences, Vol.13, pp.9-14, 1994.

9 ) Smith, R. E. ; Toward a cognitive-affective model of athletic burnout. Journal of Sport Psychology, Vol.8, pp.36-50, 1986.

10) Schmidt, G. W. and Stein, G. L. ; Sport commitment: A model integrating enjoyment, dropout, and burnout. Journal of sport and exercise psychology, Vol.13, pp.254-265, 1991.

11）山田泰行；日本の大学生競技者におけるアス リート・バーンアウトの性格要因, 順天堂大学 大学院スポーツ健康科学研究科平成 22 年度博 士論文, 2010.

12) Cremades, J. G. and Wiggins, M. S. ; Direction and intensity of trait anxiety as predictors of burnout among collegiate athletes. Athletic Insight: The Online Journal of Sport Psychology, Vol.10, No2, http : //www.athleticinsight. com/Voll0Is s2/Trait Anxiety.htm, 2008. (accessed 2014-07-11)

13) Lemyre, P. N. et al. ; Influence of variability in motivation and affect on elite athlete burnout susceptibility. Journal of Sport and Exercise Psychology, Vol.28, pp.32-48, 2006.

14）鈴木直人；ポジティブな感情と認知とその心 理的・生理的影響. 島井哲志編, ポジティブ心 理学 : 21世紀の心理学の可能性, ナカニシヤ出 版, pp.66-82, 2006.

15）山崎勝之；ポジティブ感情の役割：その現象 と機序. パーソナリティ研究, Vol.14, pp.305321, 2006.

16）田中輝海, 杉山佳生 ; バーンアウト傾向に及ぼ すポジティブ感情の改善効果 : 問題焦点型コー ピングを媒介変数として. 体育学研究, Vol.60, pp.479-488, 2015.

17）フレドリクソン, B. L. : 高橋由紀子訳; ポジティ ブな人だけがうまくいく $3: 1$ の法則, 日本実 業出版社, 2010 .
18) Fredrickson, B. L. and Branigan, C. ; Positive emotions broaden the scope of attention and thought-action repertoires. Cognition and Emotion, Vol.19, pp.313-332, 2005.

19) Fredrickson, B. L. and Joiner, T. ; Positive emotions trigger upward spirals toward emotional well-being. Psychological Science, Vol.13, pp.172-175, 2002.

20) Fredrickson, B. L. et al. ; The undoing effect of positive emotions. Motivation and emotion, Vol.24, pp.237-258, 2000.

21）田中輝海, 水落文夫 ; 男性スポーツ選手にお けるバーンアウト傾向の深刻化とポジティブ 感情の関係性, スポーツ心理学研究, Vol.40, pp.43-57, 2013.

22）古賀弘之; 音楽と感情・気分に関する研究, 広島大学大学院教育学研究科紀要, Vol. 52 , pp.45-52, 2003.

23）藤井昌志, 谷口麻起子 ; 感情特性と情動一の評 価の関連性について, 聖泉論叢, Vol.20, pp.1123, 2012.

24）石井源信 ; 心理的・コーチング的側面.(財)日本 体育協会編, 女子スポーツ・ハンドブック,ぎょ うせい, pp.16-55, 1986.

25）山崎勝之；正感情と “Finding Positive Meaning”コーピングが健康に及ぼす影響, ふくろう 出版, pp.39-51, 2009.

26) Watson, D. et al. ; Development and validation of brief measures of positive and negative affect: The PANAS scales. Journal of Personality and Social Psychology, Vol.54, pp.1063-1070, 1988.

27）佐藤 徳, 安田朝子; 日本語版PANAS の作成. 性格心理学研究, Vol.9, pp.138-139, 2001.

28) Maslach, C. and Jackson, S. E. ; The measurement of experienced burnout. Journal of Occupational Behavior, Vol.2, pp.99-113, 1981.

29）岸順治, 他 ; 運動選手のバーンアウト尺度作 成の試み. スポーツ心理学研究, Vol.15, pp.5459, 1988.

30）前田和寛；重回帰分析の応用的手法：交互作 用項ならびに統制変数を含む分析, 比治山大学 短期大学部紀要, Vol.43, pp.69-73, 2008.

31）速水敏彦; 動機づけにおける感情の役割：特 にネガティブ感情に注目して, 感情的動機づけ 
理論の展開 : やる気の素顔, ナカニシヤ出版, pp.95-123, 2012.

32) Carver, C. S. ; Negative affects deriving from the behavioral approach system. Emotion, Vol.4, pp.3-22, 2004.

33）大竹恵子; ポジティブ感情の機能と社会的行動, 島井哲志編, ポジティブ心理学 : 21 世紀の心理 学の可能性, ナカニシヤ出版, pp.83-98, 2006.

34）磯貝浩久; 自己決定理論：やる気の連続性, 中 込四郎ほか編著, よくわかるスポーツ心理学, ミネルヴァ書房, pp.84-85, 2012.

35) Raedeke, T. D. and Smith, A. L. ; Development and preliminary validation of an athlete burnout measure. Journal of Sport and Exercise Psychology, Vol.23, pp.281-306, 2001.

36）玉瀬耕治；ストレスと心理的障害, 無藤 隆, 他著, 心理学: New Liberal Arts selection, 有 斐閣, pp.449-469, 2004.

37) Raedeke, T. D. and Smith, A. L. ; Coping resources and athlete burnout: An examination of stress mediated and moderation hypothesis. Journal of Sport and Exercise Psychology, Vol.26, pp.525-541, 2004.

38) Hill, A. P. et al. ; Perfectionism and athlete burnout in junior elite athletes: The mediat- ing role of coping tendencies. Anxiety, Stress, and Coping, Vol.23, pp.415-430, 2010.

39）中島宣行, 山田泰行; 競技成績の停滞によって 生じる抑うつ反応とコーピング, 順天堂医学, Vol.53, pp.257-267, 2007.

40）渋倉崇行, 森 恭; 高校運動部員の部活動ス トレッサーに対するコーピング採用とストレ ス反応との関連, スポーツ心理学研究, Vol.29, No.2, pp.19-30, 2002.

41）岡 浩一朗, 他; 大学生アスリートの日常. 競技ストレッサー尺度の開発およびストレッ サーの評価とメンタルヘルスの関倸, 体育学研 究, Vol.43, pp.245-259, 1998.

42）阿久津洋巳, 他 ; ストレス課題によるポジティ ブ感情とネガティブ感情の変化, 岩手大学教育 学部研究年報, Vol.68, pp.1-8, 2009.

43) Fredrickson, B. L. et al. ; Open hearts build lives : positive emotions, induced through loving-kindness meditation, build consequential personal resources. Journal of personality and social psychology, Vol.95, pp.1045-1062, 2008.

44) Otake, K. et al. ; Happy people become happier through kindness : A counting kindnesses intervention. Journal of Happiness Studies, Vol.7, pp.361-375, 2006. 